\title{
Determinan Kualitas Laporan Keuangan Koperasi Pegawai Negeri: Pengujian Peran Moderasi Tingkat Penerapan Sistem Pengendalian Internal
}

\author{
Ni Ketut Siti Ardianti ${ }^{1}$, Made Aristia Prayudi ${ }^{2}$ \\ 1,2 Program Studi S1 Akuntansi, Universitas Pendidikan Ganesha \\ Singaraja, Indonesia \\ e-mail: ${ }^{1} \mid$ sitiardianti08@gmail.com, ${ }^{2} \mid$ prayudi.acc@undiksha.ac.id
}

\begin{abstract}
Abstrak
Tujuan dari penelitian ini adalah untuk membuktikan secara empiris pengaruh pemahaman akuntansi koperasi berbasis SAK-ETAP, dan pemanfaatan sistem informasi akuntansi terhadap kualitas laporan keuangan KPN serta untuk mengetahui pengaruh sistem pengendalian internal dalam memoderasi hubungan antara pemahaman akuntansi koperasi berbasis SAK-ETAP, dan pemanfaatan sistem informasi akuntansi. Metode penelitian yang digunakan adalah metode kuantitatif kausal, jenis data yang digunakan adalah data primer, menggunakan metode instrument berupa kuesioner. Sampel yang diperoleh dengan menggunakan metode purposive sampling. Teknik analisis data yang digunakan uji t dan uji interaksi (Moderated Regression Aanlysis). Hasil dari penelitian ini menunjukkan bahwa: (1) pemahaman akuntansi koperasi berbasis SAK-ETAP berpengaruh secara positif dan signifikan terhadap kualitas laporan keuangan KPN, (2) pemanfaatan sistem informasi akuntansi berpengaruh secara positif dan siginifikan terhadap kualitas laporan keuangan KPN, (3) sistem pengendalian internal memperkuat hubungan positif pemahaman akuntansi koperasi berbasis SAK-ETAP dan kualitas laporan keuangan KPN, (4) sistem pengendalian internal memperkuat hubungan positif pemanfaatan sistem informasi akuntansi dan kualitas laporan keuangan KPN.
\end{abstract}

Kata Kunci: Pemahaman akuntansi koperasi berbasis SAK-ETAP, Pemanfaatan Sistem Informasi Akuntansi, Sistem Pengendalian Internal, Kualitas Laporan Keuangan.

\section{Abstract}

The purpose of this research is to empirically prove the influence of understanding of cooperative accounting based on SAK-ETAP, and the use of accounting information systems on the quality of financial statements of KPN and to determine the effect of internal control systems in moderating the relationship between understanding of cooperative accounting based on SAK-ETAP, and the use of systems accounting information. The research method used is a causal quantitative method, the type of data used is primary data, using the instrument method in the form of a questionnaire. Samples were obtained using the purposive sampling method. Data analysis techniques used were $t$ test and interaction test (Moderated Regression Aanlysis). The results of this study indicate that: (1) understanding of cooperative accounting based on SAK-ETAP has a positive and significant effect on the quality of the KPN financial statements, (2) the use of accounting information systems has a positive and significant effect on the quality of the KPN financial statements, (3) the system internal control strengthens the positive relationship between SAK-ETAPbased cooperative accounting understanding and the quality of the KPN financial statements, (4) the internal control system strengthens the positive relationship between the utilization of accounting information systems and the quality of the KPN financial statements.

Keywords: Understanding of SAK-ETAP-based cooperative accounting, Utilization of Accounting Information Systems, Internal Control Systems, Quality of Financial Statements. 


\section{Pendahuluan}

Menurut Undang-Undang Nomor 17 Tahun 2012, Koperasi ialah suatu usaha yang dijalankan oleh orang perseorangan dengan menggunakan modal pribadi sebagai aset utamanya yang bertujuan untuk mensejahterakan anggotanya dan memiliki badan hukum dalam pendiriannya.

$\mathrm{Di}$ Indonesia terdapat berbagai jenis koperasi salah satunya adalah Koperasi Pegawai Negeri (KPN). Menurut Undang-Undang Nomor 17 Tahun 2012 tentang Perkoperasian, koperasi pegawai negeri merupakan koperasi primer yang anggotanya para pegawai negeri yang berdiri di lingkup departemen atau instansi terkait.

Menurut Permen KUKM/RI Nomor 04/Per/M.KUKM/VII/2012 tentang Pedoman Umum Akuntansi Koperasi menyatakan bahwa, koperasi dituntut memiliki pertanggungjawaban berupa laporan keuangan yang dipergunakan sebagian orang dalam menentukan suatu keputusan yang dilaporkan pada Rapat Anggota Tahunan.

Rapat Anggota Tahunan menjadi hal yang penting dalam menilai kesehatan koperasi, dengan dilaksanakannya RAT oleh koperasi akan menunjukan posisi laporan keuangan koperasi. Hasil pengawasan Dinas Koperasi dan UMKM bahwa permasalahan yang ada pada koperasi di Kabupaten Karangasem yaitu keterlambatan dan tidak dilaksanakannya RAT oleh beberapa koperasi yang menunjukkan bahwa kualitas laporan keuangan koperasi tidak baik sehingga koperasi ini mendapat penilaian yang tidak sehat. Hal ini didukung dengan adanya penilaian yang dilakukan oleh Dinas Koperasi dan UMKM terhadap laporan keuangan yang disusun koperasi yang menunjukkan bahwa laporan keuangan tersebut tidak memenenuhi aspek-aspek untuk menyatakan laporan keuangan tersebut berkualitas seperti relevan, andal, dapat dibandingkan dan dapat dipahami sehingga koperasi ini dinyatakan tidak sehat.

Koperasi Pegawai Negeri menjadi fokus kajian dalam penelitian ini dikarenakan pada Koperasi Pegawai Negeri ini masih terjadi masalah kredit macet, jika dilihat dari teori dan karakteristik KPN bahwa tingkat risiko pengembalian kreditnya sangat kecil karena ketika seseorang meminjam uang pada KPN maka dibayarnya dengan potong gaji. Namun pada kenyataannya hal ini tidak berlaku di beberapa KPN di Kabupaten Karangasem, masih banyak KPN yang mengalami permasalahan kredit macet sehingga dengan adanya hal ini beberapa KPN sulit untuk berkembang. Jika dilihat dari teori yang ada dan praktek dilapangan maka tidak berjalan sebagaimana mestinya sehingga banyak KPN di Kabupaten Karangasem sulit ntuk berkembang.

Kabupaten Karangasem menjadi tempat penelitian penulis karena dari penilaian kesehatan koperasi di seluruh kabupaten, peneliti menemukan bahwa hanya di Kabupaten Karangasem yang terdapat 47 unit Koperasi yang dikategorikan bermasalah (Dalam Pengawasan Khusus) berbeda dengan 8 Kabupaten lainnya sehingga penulis merasa bahwa Kabupaten Karangasem tempat yang tepat dijadikan sebagai objek penelitian.

Menurut Dinas Koperasi dan UMKM Kabupaten Karangasem, dinyatakan bahwa pada KPN di Kabupaten Karangasem masih ditemukan beberapa permasalahan, diantaranya yaitu pertama, pegawai koperasi dalam menjalankan tugasnya tidak sesuai dengan job description. Kedua Data administrasi cenderung tidak sesuai atau kurang sistematis. Ketiga, Pemahaman akuntansi berdasarkan SAK-ETAP di beberapa KPN belum dikuasai dengan baik oleh pengurus KPN. Keempat, Pengalaman kerja di bidang akuntansi tidak terlalu banyak dimiliki oleh pengurus. Kelima, Masih kurangnya pemahaman teknologi sehingga pemanfaatannya kurang dapat dimaksimalkan. Permasalahan ini bisa terjadi pada penyajian pelaporan keuangan KPN.

Berdasarkan permasalahan yang terjadi diatas diperlukan beberapa factor yang dapat meningkatkan kualitas pelaporan keuangan pada KPN di Kabupaten Karangasem. Pemahaman akuntansi koperasi berbasis SAK-ETAP digunakan sebagai factor utama, Menurut Riko (2012:75), tingkat pemahaman ialah sejauhmana seseorang dapat mengerti dan paham akan suatu materi dan permasalahan yang ada dapat membedakan mana yang benar dan mana yang salah. Paham akan akuntansi dapat 
dilihat dari pelaporan keuangan yang dihasilkan oleh individu, dan bagaimana proses yang dilakukan untuk mencapai pelaporan keuangan yang baik sesuai dengan SAK-ETAP. Penelitian yang berkaitan dengan pemahaman akuntansi koperasi berbasis SAK-ETAP telah banyak dilakukan oleh Adiputra (2017), Dewi (2018), Arismawati (2017) dimana dalam penelitiannya Pemahaman Akuntansi Koperasi Berbasis SAK-ETAP ini berpengaruh secara positif dan signifikan terhadap kualitas pelaporan keuangan koperasi.

$\mathrm{H}_{1}$ : Pemahaman akuntansi koperasi berbasis SAK-ETAP berpengaruh secara positif dan signifikan terhadap kualitas laporan keuangan pada koperasi pegawai negeri.

Faktor kedua yang dapat digunakan yaitu pemanfaatan sistem informasi akuntansi, untuk dapat meningkatkan efisiensi dalam organisasi diperlukan pemanfaatan sistem informasi akuntansi guna menyediakan informasi keuangan yang diperlukan Alsarayreh et al., 2011).

Sistem informasi akuntansi

pelaporan anggaran dan keuangan, membantu proses identifikasi, pengukuran, dan pengambilan keputusan ekonomi. Jadi, pemanfaatan sistem informasi akuntansi dan kualitas laporan keuangan berbanding lurus, jika semakin tinggi pemanfaatan sistem informasi akuntansi maka semakin tinggi juga kualitas laporan keuangan yang dihasilkan koperasi. Penelitian terkait pemanfaatan sistem informasi akuntansi telah banyak dilakukan oleh Dewi (2018), Evicahyani (2016), Pransisca (2016) dan Sari (2015) dimana hasil penelitiannya menunjukkan bahwa pemanfaatan sistem informasi akuntansi berpengaruh signifikan terhadap kualitas pelaporan keuangan. Namun terdapat ketidak konsistenan penelitian yang dilakukan oleh Rianisanti (2017), Artana (2016) dan Diani (2016) dimana hasil penelitian ini menunjukkan bahwa pemanfaatan sistem informasiakuntansi tidak berpengaruh terhadap kualitas pelaporan keuangan.

$\mathrm{H}_{2}$ : Pemanfaatan sistem informasi akuntansi berpengaruh positif dan signifikan terhadap kualitas laporan keuangan pada koperasi pegawai negeri.

Faktor ketiga yang dapat digunakan yaitu sistem pengendalian internal, Menurut Hery (2013:159), sistem pengendalian intern ialah suatu sistem yang dibuat oleh manajer untuk dapat mengontrol aktivitas-aktivitas yang dilakukan oleh karyawan agar tidak terjadi penyimpangan antara pembagian tugas dan wewenang. Hal ini menunjukkan bahwa jika penerapan pengendalian internal akuntansi berjalan dengan baik, maka pelaporan keuangan yang dihasilkan akan mempunyai nilai informasi yang baik. Jadi, pengendalian internal akuntansi dan kualitas laporan keuangan berbanding lurus, jika semakin tinggi pengendalian internal akuntansi, maka semakin tinggi pula kualitas pelaporan keuangan yang dihasilkan. Penelitian yang berkaitan dengan sistem pengendalian internal banyak dilakukan oleh Oktafiani (2018), Oktaviyanti (2017) dan Untary (2015) hasil penelitian ini menunjukkan bahwa secara parsial sistem pengendalian internal berpengaruh positif dan signifikan terhadap kualitas laporan keuangan. Namun terdapat ketidak konsistenan penelitian yang dilakukan oleh Suryani (2018) dimana hasil penelitian ini menunjukkan bahwa sistem pengendalian internal tidak berpengaruh terhadap kualitas laporan keuangan. Berdasarkan uraian diatas maka hipotesis ketiga dan keempat yang diajukan dalam riset ini yaitu.

$\mathrm{H}_{3}$ : Penerapan sistem pengendalian internal memoderasi hubungan antara pemahaman akuntansi koperasi berbasis SAK-ETAP dan kualitas laporan keuangan koperasi pegawai negeri.

$\mathrm{H}_{4}$ : Penerapan sistem pengendalian internal memoderasi hubungan antara pemanfaatan sistem informasi akuntansi dan kualitas laporan keuangan koperasi pegawai negeri. 


\section{Metode}

Riset ini menggunakan metode pendekatan kuantitatif kausal. Data didapatkan dari hasil penyebaran kuesioner yang telah dilakukan. Setelah data terkumpul, data-data tersebut nantinya digunakan untuk menjelaskan variabel yang digunakan. Riset ini dilakukan di Kabupaten Karangasem dengan alasan Kabupaten Karangasem memiliki jumlah KPN terbanyak yang berada dalam pengawasan khusus dari 9 Kabupaten yang ada di Bali. Populasi yang digunakan penelitian ini adalah seluruh KPN di Kabupaten Karangasem yang berjumlah 23 KPN. Penentuan sampel yaitu dengan teknik Purposive Sampling dengan pertimbangan tertentu sehingga layak dijadikan sampel. Dilihat dari hasil tersebut, jumlah sampel pada riset ini berjumlah 17 sampel dengan responden berjumlah 51 orang yang terdiri dari ketua dan staf/pegawai bagian keuangan.

Analisis yang digunakan dalam riset ini yaitu regresi linier berganda menggunakan SPSS 20, apabila data sudah terkumpul selanjutnya mulai dilakukan pengelolahan data dengan pengolahan data dengan analisis statistic yaitu : (1) analisis statistic deskriptif, (2) analisis validity, (3) analisis classic assumption yang meliputi analisis normality, analisis multikolinearitas, serta analisis heteroskedastisitas, (4) analisis hipotesis atau multiple linier regression analysis yang terdiri atas analisis regresi linier berganda, uji statistic t, uji koefisien determinasi $\left(\mathrm{R}^{2}\right)$, Uji interaksi (Moderated Regression Analysis).

\section{Hasil Dan Pembahasan}

Tabel 1. Hasil Analisis Deskriptif

\begin{tabular}{|c|c|c|c|c|c|}
\hline & $\mathrm{N}$ & Min & $\operatorname{Max}$ & Mean & $\begin{array}{c}\text { Std. } \\
\text { Deviation }\end{array}$ \\
\hline Pemahaman Akuntansi & & & & & \\
\hline $\begin{array}{l}\text { Koperasi Berbasis SAK- } \\
\text { ETAP (X1) }\end{array}$ & 51 & 35 & 45 & 40,08 & 2,296 \\
\hline $\begin{array}{l}\text { Pemanfaatan Sistem } \\
\text { Informasi Akuntansi (X2) }\end{array}$ & 51 & 31 & 41 & 36,24 & 2,421 \\
\hline $\begin{array}{l}\text { Sistem Pengendalian Internal } \\
\text { (Z) }\end{array}$ & 51 & 27 & 37 & 32,02 & 2,518 \\
\hline $\begin{array}{l}\text { Kualitas Laporan Keuangan } \\
\text { KPN (Y) }\end{array}$ & 51 & 28 & 40 & 34,55 & 3,061 \\
\hline Valid N (listwise) & 51 & & & & \\
\hline
\end{tabular}

Responden pada riset ini adalah ketua dan bendahara pada KPN di Kabupaten Karangasem. Data pada penelitian riset ini dikumpulkan dengan mmenyebar kuesioner sebanyak 51 eksemplar dan telah kembali 100\% dalam jangka waktu 4 minggu. Karakteristik responden pada penelitian ini terdiri dari jenis kelamin, usia, pendidikan terakhir, jabatan, pernah mengikuti pelatihan penyusunan laporan keuangan.

Ditinjau dari segi jenis kelamin, responden dapat dikelompokkan menjadi 2, yaitu responden laki-laki dan responden perempuan. Responden laki-laki pada penelitian ini sebanyak 27 orang atau sebesar 52,9\% dan responden perempuan pada penelitian ini sebanyak 24 orang atau sebesar 47,1\%. Hal ini menunjukkan bahwa sebagain besar responden adalah laki-laki.

Ditinjau dari segi umur, tidak terdapat responden yang berumur kurang dari 20 tahun, untuk responden yang berumur 20-29 tahun sebanyak 5 orang atau sebesar 9,8\%, umur 30-39 tahun sebanyak 20 tahun atau sebesar 39,2\%, umur 40-49 tahun sebanyak 20 orang atau sebesar 39,2\%, umur 50-59 tahun sebanyak 5 orang atau sebesar $9,8 \%$ dan yang berumur $>=60$ tahun sebanyak 1 orang atau sebesar $2,0 \%$. Hal ini menunjukkan bahwa sebagian besar responden berumur 30-49 tahun.

Ditinjau dari segi pendidikan, responden yang pendidikan terakhirnya SMA sebanyak 22 orang atau sebesar $43,1 \%$, D3 sebanyak 1 orang atau sebesar $2,0 \%$, S1 sebanyak 21 orang atau sebesar $41,2 \%$, S2 sebanyak 7 
orang atau sebesar 17,3\%. Hal ini menunjukkan bahwa sebagian besar responden memiliki pendidikan terakhir SMA sebanyak 22 orang atau sebesar $43,1 \%$.

Ditinjau dari segi jabatan, responden yang sebagai sebagai ketua sebanyak 17 orang atau sebesar $33,3 \%$ sebagai pegawai bagian keuangan (bendahara) sebanyak 34 orang atau sebesar $66,7 \%$. Hal ini menunjukkan bahwa sebagian besar responden menjabat sebagai pegawai bagian keuangan (bendahara) sebanyak 34 orang atau sebesar $66,7 \%$.

Ditinjau dari segi pernah mengikuti pelatihan penyusunan laporan keuangan atau tidak, responden yang pernah yang pernah mengikuti penyusunan laporan keuangan sebanyak 20 orang atau sebesar $39,2 \%$ dan yang tidak pernah mengikuti pelatihan penyusunan laporan keuangan sebanyak 31 orang atau sebesar $60,8 \%$. Hal ini menunjukkan bahwa sebagian besar responden belum pernah mengikuti pelatihan penyusunan laporan keuangan. Pada statistic deskriptif dikemukakan cara-cara penjelasan kelompok melalui minimum, maximum, mean, dan standar deviation.

Variabel pemahaman akuntansi koperasi berbasis SAK-ETAP $\left(\mathrm{X}_{1}\right)$ memiliki skor terendah (minimum) 35 dan skor tertinggi (maxsimum) 45 dengan skor ratarata (mean) 40,08. Hal ini menunjukkan bahwa terjadi perbedaan nilai pemahaman akuntansi koperasi berbasis SAK-ETAP $\left(X_{1}\right)$ terhadap nilai ratarata sebesar 40,08. Variabel pemanfaatan sistem informasi akuntansi $\left(X_{2}\right)$ memiliki skor terendah (minimum) 31 dan skor tertinggi (maxsimum) 41 dengan skor rata-rata (mean) 36,24. Hal ini menunjukkan bahwa terjadi perbedaan nilai pemanfaatan sistem informasi akuntansi $\left(X_{2}\right)$ terhadap nilai rata-rata sebesar 36,24.

Variabel sistem pengendalian internal (Z) memiliki skor terendah (minimum) 27 dan skor tertinggi (maxsimum) 37 dengan skor rata-rata (mean) 32,02. Hal ini menunjukkan bahwa terjadi perbedaan nilai sistem pengendalian internal sebesar 32,02. Variabel kualitas laporan keuangan KPN (Y) memiliki skor terendah (minimum) 28 dan skor tertinggi (maxsimum) 40 dengan skor rata-rata (mean) 34,55. Hal ini menunjukkan bahwa terjadi perbedaan nilai kualitas laporan keuangan KPN sebesar 34,55.

Selain itu dilakukan uji validitas dan reliabilitas. Tingkat validitas dapat diukur dengan cara membandingkan nilai $\quad R_{\text {hitung }}$ dengan $R_{\text {tabel, }}$ dengan signifikansi 0,05 . Jika $R_{\text {hitung }}>R_{\text {tabel }}$ dan nilai $r$ positif, maka butir atau pernyataan tersebut dinyatakan valid. Nilai $R_{\text {tabel }}$ pada penelitian ini dapat dilihat dengan jumlah sampel 51 diperoleh $\mathrm{df}=\mathrm{n} 2=51-2=49$, sehingga nilai $R_{\text {tabel }} \mathrm{df}=49$ dengan signifikansi 0,05 adalah 0,232. Berdasarkan hasil uji validitas semua item dinyatakan valid karena semua nilai $r_{\text {hitung }}$ pada setiap item lebih besar dari nilai $r_{\text {tabel }}$ serta telah mampu mengungkapkan sesuatu yang akan diukur pada setiap variabel.

Pengukuran reliabilitas dilakukan dengan uji statistik Cronbach Alpha melalui bantuan program (Statistical Package for Social Sciences) SPSS. Menurut Ghozali (2011) suatu kuesioner dikatakan reliabel jika memberikan nilai Cronbach Alpha $>0,70$. Setelah uji kualitas data terpenuhi dengan baik, maka dilanjutkan dengan uji asumsi klasik. Uji asumsi klasik yang pertama, yaitu uji normalitas. Dimana uji normalitas dilakukan dengan tujuan untuk menguji apakah pada model regresi memiliki nilai residual yang berdistribusi normal dengan kriteria pengujian normalitas menggunakan Uji Statistik Non-Parametik Kolmogorov-Smirnov (K-S) yang diperoleh dengan nilai signifikansi lebih besar dari 0,05 sehingga data dapat dikatakan terdistribusi dengan normal. Hasil uji normalitas pada penelitian ini disajikan pada tabel 2. Berikut:

Tabel 2. Hasil Uji Normalitas

\begin{tabular}{lc}
\hline & Unstandardized Residual \\
\hline Kolmogorov-Smirnov Z & 0,755 \\
\hline Asymp. Sig. (2-tailed) & 0,619 \\
\hline
\end{tabular}


Berdasarkan dari hasil pengujian bahwa nilai dari Kolgomorov-Smirnov sebesar 0,755 dengan nilai signifikansi yaitu sebesar 0,619> 0,05 yang artinya bahwa nilai residual berdistribusi secara normal.

Selanjutnya dilakukan uji asumsi klasik yang kedua yaitu uji multikoliniaritas. Uji ini dapat dilihat dari adanya nilai Variance Inflation Factor (VIF) dan nilai Tolerance. Apabila nilai VIF $>10$ atau tolerance $<, 10$ maka dinyatakan terjadi gejala multikolinearitas. Sebaliknya apabila nilai VIF $<10$ atau tolerance $>0,10$ maka dapat dinyatakan tidak terjadi gejala multikolinearitas. Hasil uji multikolinearitas disajikan pada tabel 3 berikut :

Tabel 3. Hasil Uji Multikolinearitas

\begin{tabular}{lccc}
\hline \multirow{2}{*}{ Model } & \multicolumn{2}{c}{ Collinearity Statistics } & \multirow{2}{*}{ Keterangan } \\
\cline { 2 - 3 } & Tolerance & VIF & \\
\hline $\begin{array}{l}\text { Pemahaman akuntansi } \\
\text { koperasi berbasis SAK- }\end{array}$ & 0,783 & 1,355 & Bebas Multikolinearitas \\
$\begin{array}{l}\text { ETAP } \\
\begin{array}{l}\text { Pemanfaatan sistem } \\
\text { informasi akuntansi }\end{array}\end{array}$ & 0,512 & 1,955 & Bebas Multikolinearitas \\
$\begin{array}{l}\text { Sistem pengendalian } \\
\text { internal }\end{array}$ & 0,510 & 1,961 & Bebas Multikolinearitas \\
\hline
\end{tabular}

Berdasarkan hasil uji multikolinearitas yang disajikan pada tabel 3 menunjukkan bahwa semua variabel independen mempunyai nilai VIF lebih kecil daripada 10 dan nilai Tolerance lebih besar 0,10, sehingga dapat disimpulkan bahwa model regresi bebas dari multiikolinearitas. Uji asumsi klasik yang selanjutnya dengan melakukan uji heteroskedastisitas. Untuk mengetahui ada tidaknya heteroskedastisitas, maka dilakukan dengan Uji Glejser. Apabila nilai signifikansi > 0,05 maka terjadi homokedastisitas yang seharusnya terjadi. Namun apabila nilai signifikansi < 0,05 maka terdapat heteroskedastisitas. Hasil uji heteroskedastisitas pada penelitian ini disajikan pada tabel 4 berikut :

Tabel 4. Hasil Uji Heteroskedastisitas

\begin{tabular}{ll}
\hline Model & Sig. \\
\hline 1 (Constant) & 0,601 \\
Pemahaman akuntansi koperasi & 0,286 \\
berbasis SAK-ETAP & \\
Pemanfaatan sistem informasi akuntansi & 0,742 \\
Sistem pengendalian internal & 0,597 \\
\hline
\end{tabular}

Tabel 5. Hasil Uji Statistik t

\begin{tabular}{|c|c|c|c|c|c|c|}
\hline \multicolumn{7}{|c|}{ Coefficients $^{a}$} \\
\hline \multirow[b]{2}{*}{ Model } & & $\begin{array}{l}\text { Unstan } \\
\text { d Coef }\end{array}$ & $\begin{array}{l}\text { dardize } \\
\text { icients }\end{array}$ & $\begin{array}{c}\text { Standardize } \\
\mathrm{d} \\
\text { Coefficients } \\
\end{array}$ & \multirow[b]{2}{*}{$\mathrm{T}$} & \multirow[b]{2}{*}{ Sig. } \\
\hline & & B & $\begin{array}{l}\text { Std. } \\
\text { Error }\end{array}$ & Beta & & \\
\hline \multirow[t]{2}{*}{1} & (Constant) & 9.196 & 6.730 & & 1.367 & .178 \\
\hline & $\begin{array}{l}\text { PemahamanAkuntan } \\
\text { siKoperasiBerbasis } \\
\text { SAK-ETAP (X1) }\end{array}$ & .633 & .168 & .475 & 3.773 & .000 \\
\hline
\end{tabular}




\begin{tabular}{|c|c|c|c|c|c|c|}
\hline \multicolumn{7}{|c|}{ Coefficients $^{a}$} \\
\hline \multirow[b]{2}{*}{ Model } & & $\begin{array}{l}\text { Unstan } \\
\text { d Coef }\end{array}$ & $\begin{array}{l}\text { dardize } \\
\text { ficients }\end{array}$ & $\begin{array}{c}\text { Standardize } \\
\text { d } \\
\text { Coefficients } \\
\end{array}$ & \multirow[b]{2}{*}{$\mathrm{T}$} & \multirow[b]{2}{*}{ Sig. } \\
\hline & & $\mathrm{B}$ & $\begin{array}{l}\text { Std. } \\
\text { Error }\end{array}$ & Beta & & \\
\hline \multirow[t]{2}{*}{1} & (Constant) & 9.196 & 6.730 & & 1.367 & .178 \\
\hline & $\begin{array}{l}\text { PemahamanAkuntan } \\
\text { siKoperasiBerbasis } \\
\text { SAK-ETAP (X1) }\end{array}$ & .633 & .168 & .475 & 3.773 & .000 \\
\hline
\end{tabular}

a. Dependent Variable: Kualitas Laporan Keuangan KPN (Y)

\begin{abstract}
Berdasarkan hasil uji heteroskedastisitas yang disajikan pada tabel 4. Dapat dilihat bahwa masing-masing variabel yaitu pemahaman akuntansi koperasi berbasis SAK-ETAP sebesar 0,286, pemanfataan sistem informasi akuntansi sebesar 0,742 , dan penerapan sistem pengendalian internal sebesar 0,597, sehingga dapat disimpulakan bahwa model regresi tidak mengandung adanya heteroskedastisitas
\end{abstract}

\begin{tabular}{|c|c|c|c|c|c|c|}
\hline \multicolumn{7}{|c|}{ Coefficients $^{a}$} \\
\hline \multirow[b]{2}{*}{ Model } & & \multicolumn{2}{|c|}{$\begin{array}{l}\text { Unstandardize } \\
\text { d Coefficients }\end{array}$} & $\begin{array}{c}\text { Standardized } \\
\text { Coefficients }\end{array}$ & \multirow[b]{2}{*}{$\mathrm{T}$} & \multirow[b]{2}{*}{ Sig. } \\
\hline & & $\mathrm{B}$ & $\begin{array}{l}\text { Std. } \\
\text { Error }\end{array}$ & Beta & & \\
\hline \multirow[t]{2}{*}{1} & (Constant) & -8.637 & 2.189 & & -3.946 & .000 \\
\hline & $\begin{array}{l}\text { PemanfaatanSisteml } \\
\text { nformasiAkuntansi } \\
\text { (X2) }\end{array}$ & 1.192 & .060 & .943 & $\begin{array}{r}19.77 \\
3\end{array}$ & .000 \\
\hline
\end{tabular}

a. Dependent Variable: KualitasLaporanKeuangan KPN (Y)

\title{
Pengaruh pemahaman akuntansi koperasi berbasis SAK-ETAP terhadap kualitas laporan keuangan KPN.
}

Berdasarkan dari hasil hipotesis pertama $\left(\mathrm{H}_{1}\right)$ dapat dilihat bahwa nilai signifikansi variabel pemahaman akuntansi koperasi berbasis SAK-ETAP (X1) sebesar 0,000<0,05 sedangkan nilai $t_{\text {hitung }} 3,733>\mathrm{t}_{\text {tabel }} 1,667$, maka dapat dinyatakan bahwa variabel pemahaman akuntansi koperasi berbasis SAK-ETAP $\left(X_{1}\right)$ mempunyai pengaruh terhadap variabel kualitas laporan keuangan KPN (Y). Hal ini menunjukkan bahwa $\mathbf{H}_{\mathbf{1}}$ diterima yaitu pemahaman akuntansi koperasi berbasis SAK-ETAP berpengaruh secara positif dan signifikan terhadap kualitas laporan keuangan KPN.

Berdasarkan agency theory dijelaskan bahwa KPN sebagai agen yang bertanggung jawab kepada principal dalam hal ini bentuk pertanggung jawaban yaitu dalam bentuk laporan keuangan KPN, untuk memenuhi kewajiban tersebut KPN harus mampu menyajikan laporan keuangan yang berkualitas, salah satu yang paling utama dalam pembuatan laporan tersebut ialah setiap pegawai pembuat laporan keuangan harus memahami standar akuntansi keuangan berbasis SAK-ETAP dengan baik sehingga mampu menghasilkan laporan keuangan yang relevan, andal, dapat dipahami dan dapat dibandingkan serta bisa menjadi informasi yang berguna bagi para pengguna laporan keuangantersebut. 
Tabel 6. Hasil Uji Moderated Regression Analysis

\begin{tabular}{|c|c|c|c|c|c|c|}
\hline \multicolumn{7}{|c|}{ Coefficients $^{a}$} \\
\hline \multirow[b]{2}{*}{ Model } & & $\begin{array}{l}\text { Unstano } \\
\text { Coeffi }\end{array}$ & $\begin{array}{l}\text { ardized } \\
\text { ients }\end{array}$ & $\begin{array}{l}\text { Standardiz } \\
\text { ed } \\
\text { Coefficient } \\
\text { s } \\
\end{array}$ & \multirow[b]{2}{*}{$\mathrm{T}$} & \multirow[b]{2}{*}{ Sig. } \\
\hline & & B & $\begin{array}{l}\text { Std. } \\
\text { Error }\end{array}$ & Beta & & \\
\hline \multirow[t]{3}{*}{1} & (Constant) & 30.513 & 4.351 & & 7.012 & .000 \\
\hline & $\begin{array}{l}\text { PemahamanAkuntansi } \\
\text { KoperasiBerbasis SAK- } \\
\text { ETAP (X1) }\end{array}$ & -.718 & .163 & -.539 & -4.407 & .000 \\
\hline & Interaksi X1 dengan Z & .026 & .002 & 1.248 & $\begin{array}{r}10.21 \\
0\end{array}$ & .000 \\
\hline
\end{tabular}

a. Dependent Variable: KualitasLaporanKeuangan KPN (Y)

Coefficients $^{\mathrm{a}}$

\begin{tabular}{|c|c|c|c|c|c|c|}
\hline \multirow[b]{2}{*}{ Model } & & \multicolumn{3}{|c|}{$\begin{array}{lc} & \text { Standardi } \\
& \text { zed } \\
\text { Unstandardize } & \text { Coefficient } \\
\text { d Coefficients } & \text { s } \\
\end{array}$} & \multirow[b]{2}{*}{$\mathrm{T}$} & \multirow[b]{2}{*}{ Sig. } \\
\hline & & B & $\begin{array}{l}\text { Std. } \\
\text { Error }\end{array}$ & Beta & & \\
\hline \multirow[t]{3}{*}{1} & (Constant) & 4.197 & 1.063 & & 3.949 & .000 \\
\hline & $\begin{array}{l}\text { PemanfaatanSistemInf } \\
\text { ormasiAkuntansi (X2) }\end{array}$ & .374 & .050 & .296 & 7.454 & .000 \\
\hline & Interaksi X2 dengan Z & .014 & .001 & .718 & $\begin{array}{r}18.08 \\
6\end{array}$ & .000 \\
\hline
\end{tabular}

a. Dependent Variable: KualitasLaporanKeuangan KPN (Y)

Hasil penelitian menunjukkan bahwa pemahaman akuntansi koperasi berbasis SAKETAP memiliki hubungan yang searah dengan kualitas laporan keuangan. Hal ini berarti bahwa semakin tinggi tingkat pemahaman akuntansi koperasi berbasis SAK-ETAP, maka laporan keuangan yang dihasilkan akan semakin berkualitas. Hasil penelitian ini sejalan dengan penelitian yang dilakukan oleh Adiputra (2017) dan Dewi (2018).

\section{Pengaruh pemanfaatan sistem informasi akuntansi terhadap kualitas laporan keuangan KPN}

Berdasarkan dari hasil hipotesis kedua $\left(\mathrm{H}_{2}\right)$ dapat dilihat bahwa nilai signifikansi variabel pemanfaatan sistem informasi akuntansi $\left(X_{2}\right)$ sebesar $0,000<$ 0,05 sedangkan nilai $t_{\text {hitung }} 19,773>t_{\text {tabel }} 1,667$, maka dapat dinyatakan bahwa variabel pemanfaatan sistem informasi akuntansi $\left(\mathrm{X}_{2}\right)$ mempunyai pengaruh terhadap kualitas laporan keuangan $(\mathrm{Y})$. Hal ini menunjukkan bahwa $\mathbf{H}_{2}$ diterima yaitu pemanfaatan sistem informasi akuntansi berpengaruh secara positif dan signifikan terhadap kualitas laporan keuangan KPN.

Hubungan antara pemanfaatan sistem informasi akuntansi terhadap kualitas laporan keuangan adalah semakin tinggi pemanfaatan sistem informasi akuntansi yang dimilki maka akan semakin berdampak pada meningkatnya 
kualitas laporan keuangan pada KPN di Kabupaten Karangasem. Hal ini tentu didukung dengan teori-teori dari literatur yang telah dipaparkan pada bab sebelumnya. Pemanfaatan sistem informasiakuntansi juga merupakan salah satu faktor yang dapat mempengaruhi kualitas laporan keuangan, Alsarayeh et al. (2011).

Berdasarkan teori dan hasil pengujian yang telah dilakukan hasil penelitian ini konsisten dengan hasil penelitian yang dilakukan oleh Evicahyani (2016), dan Sari (2015) yang menunjukkan bahwa pemanfaatan sistem informasi akuntansi keuangan daerah berpengaruh secara positif dan signifikan terhadap kualitas laporan keuangan. Penelitian ain juga dilakukan oleh Dewi (2018) dan Pransisca (2016), hasil penelitian menunjukkan bahwa sistem informasi akuntansi keuangan berpengaruh secara positif dan signifikan terhadap kualitas laporan keuangan. Sehingga dapat diambil kesimpulan dari hasil penelitian ini bahwa pemanfaatan sistem informasi akuntansi berpengaruh terhadap kualitas laporan keuangan KPN.

\section{Penerapan sistem pengendalian internal memoderasi hubungan antara pemahaman akuntansi koperasi berbasis SAK-ETAP dan kualitas} laporan keuangan koperasi pegawai negeri.

Berdasarkan dari hasil hipotesis ketiga $\left(\mathrm{H}_{3}\right)$ menunjukkan bahwa penerapan sistem pengendalian internal memoderasi hubungan antara pemahaman akuntansi koperasi berbasis SAK-ETAP dan kualitas laporan keuangan KPN. Dapat dilihat bahwa nilai signifikansi pada moderasi sistem pengendalian internal terhadap pemahaman akuntansi koperasi berbasis SAK-ETAP dan kualitas laporan keuangan KPN sebesar $0,000<$ 0,05 sedangkan nilai $t_{\text {hitung }} 10,210>t_{\text {tabel }}$ 1,677 artinya penerapan sistem pengendalian internal mampu memoderasi hubungan antara pemahaman akuntansi koperasi berbasis SAK-ETAP dan kualitas laporan.keuangan KPN. Jadi dapat disimpulkan bahwa $\mathbf{H}_{3}$ diterima yaitu penerapan sistem pengendalian internal memoderasi hubungan antara pemahaman akuntansi koperasi berbasis SAK-ETAP dan kualitas laporan keuangan KPN.

Nilai koefisien regresi variabel moderasi penerapan sistem pengendalian internal terhadap hubungan pemahaman akuntansi koperasi berbasis SAK-ETAP dan kualitas laporan keuangan KPN sebesar 0,026 tanda positif pada koefisien tersebut menandakan bahwa penerapan sistem pengendalian internal memperkuat hubungan antara pemahaman akuntansi koperasi berbasis SAK-ETAP dan kualitas laporan keuangan KPN.

Sistem pengendalian internal dikatakan mampu memperkuat hubungan antara pemahaman akuntansi koperasi berbasis SAK-ETAP dan kualitas laporan keuangan karena laporan keuangan akan lebih berkualitas pada KPN yang karyawannya memiliki pemahaman akuntansi koperasi berbasis SAK-ETAP tinggi dan dengan menerapkan sistem pengendalian internal yang kuat, dibandingkan dengan KPN yang penerapan sistem pengendalian internalnya lemah.

\section{Penerapan sistem pengendalian internal memoderasi hubungan antara pemanfaatan sistem informasi akuntansi dan kualitas laporan keuangan koperasi pegawai negeri.}

Berdasarkan dari hasil hipotesis ketiga $\left(\mathrm{H}_{4}\right)$ menunjukkan bahwa penerapan sistem pengendalian internal memoderasi hubungan antara pemanfaatan sistem informasi akuntansi dan kualitas laporan keuangan KPN. Dapat dilihat bahwa nilai signifikansi pada moderasi penerapan sistem pengendalian internal terhadap pemanfaatan sistem informasi akuntansi dan kualitas laporan keuangan KPN sebesar $0,000<0,05$ sedangkan nilai thitung $18,086>t_{\text {tabel }} 1,677$ artinya sistem pengendalian internal mampu memoderasi hubungan antara pemanfaatan sistem informasi akuntansi dan kualitas laporan keuangan KPN. Jadi dapat disimpulkan bahwa $\mathbf{H}_{\mathbf{4}}$ diterima yaitu penerapan sistem pengendalian internal memoderasi hubungan antara pemanfaatan sistem informasi akuntansi dan kualitas laporan keuangan KPN. 
Nilai koefisien regresi variabel moderasi penerapan sistem pengendalian internal terhadap hubungan pemanfaatan sistem informasi akuntansi dan kualitas laporan keuangan KPN sebesar 0,014 tanda positif pada koefisien tersebut menandakan bahwa sistem pengendalian internal memperkuat hubungan antara pemanfaatan sistem informasi akuntansi dan kualitas laporan keuangan KPN. Secara teknis sistem pengendalian internal dikatakan mampu memperkuat hubungan antara pemanfaatan sistem informasi akuntansi dan kualitas laporan keuangan karena laporan keuangan akan lebih berkualitas pada KPN dengan pemanfaatan sistem informasi yang tinggi dan dengan menerapkan sistem pengendalian internal yang kuat, dibandingkan dengan KPN yang penerapan sistem pengendalian internalnya lemah.

Penelitian ini berbeda dengan penelitian yang dilakukan oleh Rianisanti (2017) bahwa sistem pengendalian intern tidak memoderasi hubungan antara pemanfaatan sistem informasi akuntansi keuangan daerah terhadap kualitas laporan keuangan pemerintah daerah. Namun pada penelitian ini penerapan sistem pengendalian internal memoderasi hubungan antara sistem informasi akuntansi dan kualitas laporan keuangan KPN.

\section{Simpulan Dan Saran}

Berdasarkan hasil uji dan pembahasan yang telah dilakukan maka dapat ditarik simpulan, yaitu: pertama, Pemahaman akuntansi koperasi berbasis SAKETAP berpengaruh secara positif dan signifikan terhadap kualitas laporan keuangan KPN. Kedua, Pemanfaatan sistem informasi akuntansi berpengaruh secara positif dan signifikan terhadap kualitas laporan keuangan KPN. Ketiga, Penerapan sistem pengendalian internal memoderasi hubungan antara pemahaman akuntansi koperasi berbasis SAK-ETAP dan kualitas laporan keuangan KPN dan keempat, Penerapan sistem pengendalian internal memoderasi hubungan antara pemanfaatan sistem informasi akuntansi dan kualitas laporan keuangan KPN.

Berdasarkan simpulan tersebut, adapun saran yang dapat diberikan pada penelitian ini, yaitu: pertama, bagi pihak KPN diharapkan lebih meningkatkan sistem pengendalian internal dalam menjalankan tugas wewenang dan tanggung jawab pada KPN, dapat memaksimalkan pemanfaatan sistem informasi akuntansi dengan baik, sehingga dalam penyusunan laporan keuangan dapat meminimalisir kekeliruan dan dalam pembuatannya dapat diselesaikan tepat waktu sehingga bisa mengefisiensikan waktu. Kedua, Peneliti selanjutnya diharapkan dapat menambah variabel bebas lainnya yang mempengaruhi kualitas laporan keuangan dikarenakan dalam penelitian ini dilihat dari uji determinasi masih terdapat faktor lain yang mempengaruhi kualitas laporan keuangan selain yang dijelaskan oleh peneliti, peneliti selanjutnya disarankan menambah jumlah sampel dengan cara menambah luas wilayah penelitian, sehingga diharapkan hasil penelitian akan lebih baik.

\section{Daftar Pustaka}

Adiputra. 2017. Pengaruh Pemahaman Akuntansi Berbasis SAK-ETAP, Kualitas Pelatihan, dan Sistem Pengendalian Internal Terhadap Kualitas Laporan Keuangan Koperasi (Studi Empiris Pada Koperasi Simpan Pinjam di Kecamatan Karangasem). Skripsi. Fakultas Ekonomi. Singaraja:Universitas Pendidikan Ganesha.

Alsarayreh M. N., Jawabreh O. A., Jaradat M. F., and Alamro S. A. 2011. Technological Impact on Effectiveness of Accounting Information System (AIS) Applied by Aqaba Tourist Hotels. European Journal of Scientific Research, Vol 59 No (3), Hal 361-369.

Arismawati. 2017. Pengaruh Tingkat Pendidikan, Pemahaman Akuntansi Koperasi Berbasis SAK-ETAP, Kematangan Usia, Perilaku, dan Efektivitas Kinerja Terhadap Kualitas Laporan Keuangan Koperasi Simpan Pinjam di Kabupaten Buleleng (Studi Kasus Pada 
Koperasi Simpan Pinjam di Kecamatan Buleleng, Sawan, Kubutambahan, dan Tejakula). Skripsi. Fakultas Ekonomi. Singaraja:Universitas Pendidikan Ganesha.

Dewi, Eka Dianita Marvilianti dan I Putu Hendra Martadinata. 2018. Akuntansi Koperasi dan UMKM. Singaraja : Undiksha Press.

Ghozali, Imam. 2011. Aplikasi Analisis Multivariate Dengan Program SPSS. Semarang: Badan Penerbit Universitas Diponegoro

Ikatan Akuntan Indonesia. 2012. Standar Akuntansi Keuangan (SAK). Jakarta: Salemba Empat. Diakses pada tanggal 25 September 2019.

Nopiyani, Putu Eka. 2018. Pengaruh IOS Pada Nilai Perusahaan dengan Kualitas Laba sebagai Variabel Pemoderasi. Jurnal IImiah Akuntansi, Vol 3,(1) 2018.

Noviyanti, Ayu. 2018. Moderasi Pengakuan Profesional pada Hubungan Pemahaman Kode Etik Profesi dan Pemilihan Karir Sebagai Akuntan. Jurnal IImiah Akuntansi, Vol 3,(2) 2018.

Peraturan Menteri Negara Koperasi dan Usaha Kecil dan Menengah Repunlik Indonesia Nomor: 14/Per/M.KUKM/XII/2009 tentang Perubahan Atas Peraturan Menteri Negara Koperasi dan Usaha Kecil dan Menengah Nomor: 20/Per/M.KUKM/XI/2008 tentang Pedoman Penilaian Kesehatan Koperasi Simpan Pinjam dan Unit Simpan Pinjam Koperasi. 2009. Jakarta

Peraturan Menteri Negara Koperasi dan Usaha Kecil dan Menengah Repunlik Indonesia Nomor: 20/Per/M.KUKM/XI/2008 tentang Pedoman Penilaian Kesehatan Koperasi Simpan Pinjam dan Unit Simpan Pinjam Koperasi. 2008. Jakarta

Puspa Dewi Ayu. 2018. Pengaruh Pemahaman Akuntansi Koperasi Berbasis SAK-ETAP, Pemanfaatan Sistem Informasi Akuntansi, dan Pengendalian Intern Akuntansi Terhadap Kualitas Laporan Keuangan (Studi Kasus Pada Koperasi Simpan Pinjam di Kecamatam Buleleng). Skripsi. Fakultas Ekonomi. Singaraja:Universitas Pendidikan Ganesha.

Rafid, Rashwan Zuhudy. 2016. Pengaruh Pemahaman Akuntansi Pemerintahan dan Pemanfaatan Sistem Informasi Akuntansi Terhadap Kualitas Laporan Keuangan dengan Kompetensi Sumber Daya Manusia Sebagai Variabel Pemoderasi. Skripsi. Fakultas Ekonomi dan Bisnis Islam. Makassar:Universitas Islam Negeri Alauddin.

Rianisanti, Meta Dewi. 2017. Pemanfaatan Sistem Informasi Akuntansi Keuangan Daerah Dan Kapasitas Sumber Daya Manusia Terhadap Kualitas Laporan Keuangan Pemerintah Derah Dengan Sistem Pengendalian Intern Sebagai Variabel Moderating (Studi Pada Skpd Kabupaten Klaten). Di kutip dari http://eprints.iainsurakarta.ac.id/856/1/Skripsi\%20Full.pdf. Diakses pada tanggal 13 Maret 2020. 